\title{
The Characteristic of Taro Flour Based Pasta with Addition of Modified Starch and Hydrocolloids
}

\author{
Highlight: Taro Flour, Pasta, Modified Starch, Hydrocolloid
}

\author{
1,* Sonia, ${ }^{1}$ Elisa Julianti, ${ }^{1}$ Ridwansyah \\ 1) Department of Food Science and Technology, Faculty of Agriculture, University of Sumatera Utara, Medan, Indonesia. \\ Jalan Prof A Sofyan No 3 Medan, 20155. \\ *) Corresponding author email: thelimchick@gmail.com.
}

\begin{abstract}
One way to help people with coeliac disease to be able to eat gluten-based food is by creating gluten-free food like a pasta made of taro flour with modified starches and hydrocolloids addition. The research was carried to find the best spaghetti combination based on its physicochemical properties. The pasta was made by using the heat moisture treatment of modified starch of banana and potato, combined with taro flour with the proportion 0\%:30\%:70\%, 7.5\%:22.5\%:70\%, 15\%:15\%:70\%, 22.5\%:7.5\%:70\% and 30\%:0\%:70\% and added with $0.5 \%$ of hydrocolloids such as xanthan gum, carboxyl methylcellulose (CMC) and Arabic gum. The result showed that the proportion of flour and starches of the increment of modified banana starch could cause longer cooking time and higher protein content, meanwhile the increment of modified potato starch caused higher crude fiber content. Cooking loss of flour and starch proportion was considered high and elongation was very low. The addition of xanthan gum caused longer cooking time, lesser cooking loss and higher elongation and crude fiber content.
\end{abstract}

Keywords: Spaghetti, Taro Flour, Modified Starch and Hydrocolloids

\section{INTRODUCTION}

Coeliac disease is a chronic, autoimmune disorder that was caused by gluten ingestion in predisposed individuals which causes malabsorption (Balaban et al., 2019). It shows different features compared with other autoimmune disorders, such as mucosal damage that recovered completely in addition to the reversibility of its progression and chronic dynamics with avoiding gluten completely (Parzanese et al., 2017). This disease is common in Europe, North and South America, Australia, South-West Asia, and North Africa, while it is rare to happen in East Asia (Poddighe et al., 2019).

Pasta is the main food of the Italian that is made by mixing semolina wheat flour with water (Padalino et al., 2011). The mixed dough of the mixture can be shaped into many kinds of pasta (Stuknyte et al., 2013). Semolina is the main ingredient in producing pasta which contains gluten that consists of gliadin and glutenin. Gluten is able to coagulate and trap the starch component when pasta is cooked to form a protein complex network and create stable viscoelasticity (Laleg et al., 2016). Several types of pasta that are produced; one of which is spaghetti. In order to create gluten-free pasta, the general ingredient of spaghetti can be replaced with other gluten-free ingredients such as white rice, brown rice, corn, and beans (Hager et al., 2012).

Standar Nasional Indonesia (SNI), a quality management system for products, number 01-4454-1998 stated that spaghetti is a dried and long rounded stick-shaped product made of wheat flour, that could be added with or without any additives and allowed additives. Spaghetti was made through an extrusion process with 1.4 to $2.5 \mathrm{~mm}$ diameter (BSN, 1998). According to USDA, spaghetti, one of the pasta product, has a length of 21.59 to $27.94 \mathrm{~cm}$. Pasta must have a firm, but tender texture and not sticky or mushy. The pasta must have its own color, flavor and odor attribute. When the pasta is cooked it must not break up and must not adhere in a mass that cannot be set apart using a fork (USDA, 2009).

Taro (Colocasia esculenta) is a tropical root crop derived from Southeast Asia and is the staple food for people living in tropical and subtropical countries (Rashmi et al., 2018). It is also known to be easily digestible inside the human body since it has small starch granules and nonallergic properties (Pereira et al., 2015). The tuber has high carbohydrate, mineral and fiber content but low protein and fat content (Temesgen and Retta, 2015). However, taro is not commonly used as an ingredient in food making since it causes itching. Hence, the used of taro in making pasta could increase its economic value. Banana is known as the world's largest herbaceous plant and can be found widely in many developing countries. It is also considered as the fourth important crop after rice, wheat, and maize. Banana also perishes quickly, and its processing into starch becomes an interest of possible resource for food and other industrial purposes since its starch concentration is high (more than $70 \%$ of dry weight) (Waliszewski et al., 2003). Potato is used as a source of starch in the food industry. It is a crucial ingredient in producing various types of noodles. Potato starch that was used in the noodle-making is desirable since it has a clear appearance and hard texture (Noda et al., 2006). These ingredients could serve as a substitute for common ingredients for making pasta.

Heat moisture treatment is a physical treatment of starch to modify its molecular alignment without disrupting the granule (Adebowale et. al., 2005). Starch with heat moisture treatment modification could increase its resistant toward 
heat, mechanical treatment, and low $\mathrm{pH}$ by increasing the pasting temperature and decreasing the swelling power (Jacobs and Delcour, 1998).

Xanthan gum (XG) can form a thin film that can act as gluten when used in a product making like bread, cake, or noodle (Waruwu et al., 2015). Carboxymethyl cellulose (CMC) is a water-soluble polysaccharide that could affect starch gelatinization and retrogradation (Leite et al., 2012). Arabic gum (AG) consists of polysaccharide and glycoprotein. The arabinogalactan chain of Arabic gum could bond with protein to form arabinogalactoprotein. Arabinogalactan structure could create low viscosity solution and protein to create a stable emulsion (Wüstenberg, 2015). The aim of the study is to find the best combination of flour, starch, and hydrocolloids based on the cooking time, cooking loss, and the elongation of spaghetti.

\section{MATERIALS AND METHODS}

The materials used were physiological mature Kepok banana, red-skinned potato and yellowish-white flesh taro. All were obtained from Pasar Induk Tuntungan, Medan. The chemicals used were sodium metabisulphite Merck brand and brine solution.

\section{Modified Banana Starch Preparation}

The banana was peeled, cut into slices, soaked in 2000 ppm sodium metabisulphite solution for $15 \mathrm{~min}$ then blended with the water with a proportion of $1: 1$. The puree was strained with straining cloth and added with water with a proportion of 3:1 for the extraction. The extract was dried in the drying oven at $50^{\circ} \mathrm{C}$ for $12 \mathrm{~h}$ and powdered afterwards to turn it into starch. This banana starch was then increased its moisture content by $25 \%$ by spraying water into it and stored inside the refrigerator at $6^{\circ} \mathrm{C}$ for 12 h. Moisture increment was conducted to alter the molecular arrangement. The properties of HMT starch was better than the native. It has higher gel capacity, improved in solubility and swelling power and increased in water binding capacity (Adebowale et al., 2005). Starch was heated in the autoclave at $110^{\circ} \mathrm{C}$ for $3 \mathrm{~h}$ and left for $30 \mathrm{~min}$. The starch was then dried in the drying oven at $50^{\circ} \mathrm{C}$ for $4 \mathrm{~h}$, then powdered with a mixer grinder, sifted using 80 mesh sifter and kept in plastic. Analysis of parameters including analysis of color (Hutching, 1999), bulk density, pasting properties, amylose content and starch content (Apriyantono et al., 1989), water absorption and oil absorption capacity (Sathe and Salunkhe, 1981), swelling power (Leach et al., 1959) and solubility (Anderson, 1982).

\section{Modified Potato Starch Preparation}

The potato was peeled, cut into slices and soaked in 5\% brine solution for $30 \mathrm{~min}$. The next procedures were the same as making modified banana starch. The analysis of parameters was the same with modified banana starch.

\section{Taro Flour Preparation}

The taro was peeled, cut into flat chip slices, and soaked in $10 \%$ brine solution for $2 \mathrm{~h}$. Taro chips were then placed on the baking tray and dried in the drying oven at $60^{\circ} \mathrm{C}$ for $24 \mathrm{~h}$, then powdered using a mixer grinder, sifted using 80 mesh sifter and kept in plastic. Analysis of parameters including analysis of color, bulk density, pasting properties, oxalate content (Ukpabi and Ejidoh, 1981), tannin test (AOAC, 1995), amylose and starch content, water absorption, and oil absorption capacity, swelling power, and solubility.

\section{Spaghetti Making}

The formulas of the proportion of modified banana starch, potato starch, and taro flour were

$$
\begin{array}{ll}
\mathrm{T}_{1} & =0 \%: 30 \%: 70 \% \\
\mathrm{~T}_{2} & =7.5 \%: 22.5 \%: 70 \% \\
\mathrm{~T}_{3} & =15 \%: 15 \%: 70 \% \\
\mathrm{~T}_{4} & =22.5 \%: 7.5 \%: 70 \% \\
\mathrm{~T}_{5} & =30 \%: 0 \%: 70 \%
\end{array}
$$

While the hydrocolloids with $0.5 \%$ concentration were

$$
\begin{array}{ll}
\mathrm{H}_{1} & =\text { Xanthan gum } \\
\mathrm{H}_{2} & =\text { Carboxymethyl cellulose } \\
\mathrm{H}_{3} & =\text { Arabic gum }
\end{array}
$$

The taro flour, modified banana starch, and potato starch (250 g), hydrocolloids (1.25 g), and water (210 g) were mixed together into a dough. The dough was kneaded and shaped by pasta maker. Spaghetti strands were arranged on the baking tray. The strands were dried in the drying oven at $60^{\circ} \mathrm{C}$ for $12 \mathrm{~h}$, then it was sealed in plastic. Analysis of parameters included the analysis of color, cooking loss, cooking time, elongation and protein and crude fiber content (Apriyantono et al., 1989).

\section{Color Analysis}

This was conducted using chromameter (Minolta CR 400 Japan) with L, a, b system. Briefly, $5 \mathrm{~g}$ of sample was put into a transparent plastic and measured using the chromameter. Color analysis can be measured as follows:

$$
{ }^{\mathrm{o}} \mathrm{Hue}=\tan ^{-1} \frac{\mathrm{b}}{\mathrm{a}} \quad \text { Equation (1) }
$$

\section{Analysis of Bulk Density}

The sample was put into a measuring cylinder and set until it reached $100 \mathrm{ml}$ of volume. Then, the sample was weighed. Bulk density can be measured by sample weight per reached volume.

\section{Analysis of Pasting Properties}

Pasting properties analysis was measured using Rapid Visco Analyzer (RVA Tecmaster Newport Scientific, Australia). Three grams of flour or starch was dissolved in $25 \mathrm{ml}$ of distilled water. First, it was measured at $50^{\circ} \mathrm{C}$ for $1 \mathrm{~min}$ and heated until $95^{\circ} \mathrm{C}$ for $7.5 \mathrm{~min}$ and held for $5 \mathrm{~min}$. The sample was cooled back to $50^{\circ} \mathrm{C}$ for $7.5 \mathrm{~min}$ and held for $2 \mathrm{~min}$. During the process, rotating speed was set at $160 \mathrm{rpm}$. The properties that were determined were peak viscosity, trough viscosity, final viscosity, breakdown viscosity, setback viscosity, and pasting temperature.

\section{Analysis of Amylose Content}

Briefly, $0.1 \mathrm{~g}$ of sample was added with $1 \mathrm{ml}$ of $95 \%$ ethanol and $9 \mathrm{ml}$ of $1 \mathrm{~N} \mathrm{NaOH}$ in a tube. The compound was heated in a water bath for $10 \mathrm{~min}$. After the compound has cooled down, it was put into a volumetric flask and 
added with distilled water until the volume reached $100 \mathrm{ml}$. Then, $5 \mathrm{ml}$ of the solution was taken and put into another volumetric flask, added with $1 \mathrm{ml}$ of $1 \mathrm{~N}$ acetic acid, $2 \mathrm{ml}$ of iodine and added with distilled water until it reached 100 $\mathrm{ml}$ of volume. This solution was shaken and set for $20 \mathrm{~min}$. Later on, it was measured using UV-Vis Spectrophotometer (Thermo Fisher Scientific, USA) at $625 \mathrm{~nm}$ wavelength. The amylose content then measured using the absorbance value as follows:

$$
\text { Amylose Content }=\frac{\mathrm{a} \times \mathrm{v} \times \mathrm{d}}{\mathrm{s}} \times 100 \% \quad \text { Equation (2) }
$$

$\mathrm{a}=$ Amylose concentration from standard curve $(\mathrm{mg} / \mathrm{ml})$

$\mathrm{v}=$ Initial volume $(\mathrm{ml})$

$\mathrm{d}=$ Dilution factor

$\mathrm{s}=$ Sample weight $(\mathrm{mg})$

\section{Analysis of Starch Content}

Two grams of flour or starch was put into a $250 \mathrm{ml}$ beaker glass, added with $50 \mathrm{ml}$ of alcohol and stirred for $1 \mathrm{~h}$. The mixture was filtered using filter paper and cleanse with distilled water until the filter volume reached $250 \mathrm{ml}$. The remaining on the paper was put into a $250 \mathrm{ml}$ Erlenmeyer and added with $200 \mathrm{ml}$ distilled water, and $20 \mathrm{ml}$ of $25 \% \mathrm{HCl}$ then heated on a heater for $2.5 \mathrm{~h}$ at $100^{\circ} \mathrm{C}$. The Erlenmeyer was let to cool down, and the mixture was neutralized with $45 \% \mathrm{NaOH}$, then added with distilled water until it reached $500 \mathrm{ml}$ of solution. This solution was filtered and added with dinitrosalicylic acid. The starch content can be measured with the absorbance value using UV-Vis Spectrophotometer (Thermo Fisher Scientific, USA) at $550 \mathrm{~nm}$ wavelength as follows:

Starch Content $=\left(\frac{0.9 \times \mathrm{g} \times \mathrm{d}}{\mathrm{s}}\right) \times 100 \% \quad$ Equation (3)

$0.90=$ molecule weight comparing factor of 1 unit of glucose in a starch molecule

$\mathrm{g}=$ glucose concentration from standard curve $(\mathrm{mg} / \mathrm{ml})$

$\mathrm{d}=$ dilution factor

$\mathrm{s}=$ sample weight $(\mathrm{mg})$

\section{Analysis of Water Absorption and Oil Absorption Capacity}

The sample $(1 \mathrm{~g})$ was diluted into $10 \mathrm{ml}$ of distilled water or oil in a centrifuge tube. It was centrifugated with $3000 \mathrm{rpm}$ speed for 30 seconds. Then, water or oil was disposed and the supernatant was weighed. The water and oil absorption capacity can be measured as follows:

$$
\mathrm{AC}=\frac{\mathrm{W}_{1}}{\mathrm{~W}_{0}} \quad \text { Equation (4) }
$$

AC $=$ Water (or oil) absorption capacity $(\mathrm{g} / \mathrm{g})$

$\mathrm{W} 1=$ Supernatant weight $(\mathrm{g})$

W0 = Initial sample weight $(\mathrm{g})$

\section{Analysis of Swelling Power}

The sample $(1 \mathrm{~g})$ was diluted into $10 \mathrm{ml}$ of distilled water in a centrifuge tube and heated at $90^{\circ} \mathrm{C}$ for $30 \mathrm{~min}$ in a water bath while being stirred. The compound was centrifugated with $2200 \mathrm{rpm}$ speed for $30 \mathrm{~min}$. Then, the liquid was disposed and the supernatant was weighed. Swelling power can be measured as follows:

$$
\begin{array}{lll}
\mathrm{SP}=\frac{\mathrm{S}_{1}}{\mathrm{~S}_{0}} & & \text { Equation (5) } \\
\mathrm{SP} & =\text { Swelling power }(\mathrm{g} / \mathrm{g}) & \\
\mathrm{S}_{1} & =\text { Supernatant weight }(\mathrm{g}) & \\
\mathrm{S}_{0} & =\text { Initial sample weight }(\mathrm{g})
\end{array}
$$

\section{Analysis of Solubility}

The sample $(1 \mathrm{~g})$ was diluted into $10 \mathrm{ml}$ of distilled water in a centrifuge tube and heated at $90^{\circ} \mathrm{C}$ for $30 \mathrm{~min}$ in a water bath while being stirred. The compound was centrifugated with $2200 \mathrm{rpm}$ speed for $30 \mathrm{~min}$. Then, the supernatant was put in a porcelain cup and dried at $105^{\circ} \mathrm{C}$ in the oven until it reached a constant weight. The dried supernatant was weighed. Solubility can be measured as follows:

$$
\begin{array}{ll}
\mathrm{S}=\frac{\mathrm{O}_{2}}{\mathrm{O}_{1}} \times 100 \% \\
\mathrm{~S} & =\text { Solubility }(\%) \\
\mathrm{O} 2 & =\text { Dried supernatant weight }(\mathrm{g}) \\
\mathrm{O} 1 & =\text { Initial sample weight }(\mathrm{g})
\end{array}
$$$$
\text { Equation (6) }
$$

\section{Analysis of Cooking Time and Cooking Loss}

The sample $(5 \mathrm{~g})$ was boiled in $150 \mathrm{ml}$ of water. After the sample had reached the boiling optimum time, it was soaked in cold water and drained. The sample was weighed and dried at $105^{\circ} \mathrm{C}$ in drying oven until it reached the constant weight. Cooking loss equation is measured as follows:

$$
\begin{gathered}
\text { Cooking loss }(\%)=1-\frac{\text { Dried sample weight }(\mathrm{g})}{\text { Initial weight }(\mathrm{g}) \times(1-\text { sample moisture content }(\%))} \times 100 \% \\
\text { Equation }(7)
\end{gathered}
$$

\section{Analysis of Oxalate Content}

The sample $(2 \mathrm{~g})$ was added into $190 \mathrm{ml}$ of distilled water, added with $10 \mathrm{ml}$ of $6 \mathrm{~N}$ of $\mathrm{HCl}$. The mixture was heated at $100^{\circ} \mathrm{C}$ for $1 \mathrm{~h}$, cooled down, and added with distilled water until it reached $250 \mathrm{ml}$ of solution, then filtered. The filter was taken $125 \mathrm{ml}$ and diluted until its solution volume reached $300 \mathrm{ml}$. From that solution, $125 \mathrm{ml}$ of the volume was taken and was heated until it almost boiled, then it was titrated with $0.05 \mathrm{M} \mathrm{KMnO}_{4}$ until it changed from a pink color to transparent for about 30 seconds. The equation is as follows:

$$
\begin{gathered}
\text { Oxalate Content }(\mathrm{mg} / 100 \mathrm{~g})=\frac{\mathrm{KMnO}_{4} \text { volume } \times 0.00225 \times 2.4}{\text { sample weight } \times 5} \times 100 \% \\
\text { Equation }(8)
\end{gathered}
$$

\section{Elongation}

The sample was boiled in boiling water for $9 \mathrm{~min}$. Then, the strands with 5 to $10 \mathrm{~cm}$ long ends were clasped using Universal Testing Machine Zwick Type Z0.5. The breaking force was measured with $\mathrm{F} \max (\mathrm{N})$ and extensibility force or elongation was measured with $\mathrm{F}$ strain (\%).

\section{Tannin Test}

The sample $(2 \mathrm{~g})$ was added with $1 \mathrm{ml}$ of $10 \%$ of $\mathrm{NaCl}$ solution and filtered. Then, the sample was added with 
$1 \%$ of $\mathrm{FeCl}_{3}$ solution if the test is positive, then the color changes to blue.

\section{Protein Content}

The sample ( $1 \mathrm{~g}$ ) was put into a Kjeldahl tube and was added with $15 \mathrm{ml}$ of concentrated $\mathrm{H}_{2} \mathrm{SO}_{4}$ and Kjeldahl tablet as a catalyst. It was digested at $300^{\circ} \mathrm{C}$ for 4 to $6 \mathrm{~h}$ using digestion equipment (Kjeldatherm Gerhardt, Germany). Then, the tube was cooled down. The sample was then distilled and added with $30 \mathrm{ml}$ of $40 \%$ of $\mathrm{NaOH}$ solution and cleansed with $40 \mathrm{ml}$ of distilled water. Then the sample was added with $60 \mathrm{ml}$ of $4 \%$ of $\mathrm{HBO}_{3}$ solution and titrated with 0.1 $\mathrm{N} \mathrm{HCl}$ solution (Vapodest 45s Gerhardt, Germany). The equation is as follows:

$$
\text { Protein Content }(\%)=\frac{\left(\mathrm{P}_{2}-\mathrm{P}_{1}\right) \times \mathrm{N} \times 14.01 \times \mathrm{CF}}{\mathrm{P}_{0} \times 1000} \times 100 \%
$$

Equation (9)

$\mathrm{P}_{0}=$ Sample weight

$\mathrm{P}_{1}=\mathrm{HCl}$ volume for blank titration $(\mathrm{ml})$

$\mathrm{P}_{2}=\mathrm{HCl}$ volume for sample titration $(\mathrm{ml})$

$\mathrm{N}=\mathrm{HCl}$ normality

$\mathrm{CF}=$ Conversion factor $(5.7)$

\section{Crude Fiber Content}

The sample ( $2 \mathrm{~g}$ ) was added with $100 \mathrm{ml}$ of $0.325 \mathrm{~N} \mathrm{H}_{2} \mathrm{SO}_{4}$ in an Erlenmeyer. The sample was heated in an autoclave at $121^{\circ} \mathrm{C}$ for $15 \mathrm{~min}$. The sample was let to cool down. This mixture was added with $50 \mathrm{ml}$ of $1.25 \mathrm{~N} \mathrm{NaOH}$ and was heated for $15 \mathrm{~min}$. Then, it was filtered with Whatman paper No. 41 (the paper had been dried and weighed). The paper was cleansed with hot distilled water, $25 \mathrm{ml}$ of $\mathrm{H}_{2} \mathrm{SO}_{4}$, distilled water again, then $25 \mathrm{ml}$ of $9 \%$ ethanol. It was dried in the oven for $1 \mathrm{~h}$, then continued until it reached the constant weight. The equation is as follows:

$$
\text { Crude Fiber Content }=\frac{\mathrm{C}_{2}-\mathrm{C}_{1}}{\mathrm{C}_{0}} \times 100 \% \quad \text { Equation (10) }
$$

$\mathrm{C} 0=$ Sample weight $(\mathrm{g})$

$\mathrm{C} 1=$ Filter paper weight $(\mathrm{g})$

$\mathrm{C} 2=$ Fiber weight with filter paper weight $(\mathrm{g})$

\section{Statistical Analysis}

Data with three replications were analyzed using Microsoft Excel 2013. The mean differences were determined by using analysis of variance (ANOVA) and Duncan's Multiple Range Test at a significance level of $p<0.01$.

\section{RESULTS AND DISCUSSIONS}

Table 1 showed the physical, chemical, and functional properties of raw material for making composite flour such as taro flour, modified banana starch, and modified potato starch. The lowest to highest colour (hue) value of the three ingredients were demonstrated respectively by modified potato starch, modified banana starch, and taro flour. The highest L and A values were found in modified potato starch, meaning that it had brighter and redder colour than taro flour and modified banana starch. The highest $B$ value was found in taro flour, but the value was not a big difference compared to modified banana starch, meaning that they had more yellow color than modified potato starch. L and $A$ values are considered more important than $B$ value. The colour value contributes to the point of sale of a product, which means it will be more desirable with the higher value (Dhiraj and Prabhasankar, 2013).

The lowest bulk density to the highest was found in taro flour, modified banana starch, and modified potato starch. The value of bulk density indicated the content of flour or starch that fit in a package.

Peak viscosity indicated the swelling of starch before the physical breakdown. The final viscosity of a starch indicated that a viscous gel was formed after cooking and cooling (Afifah and Ratnawati, 2017). Modified banana starch had a high peak and final viscosity, hence it is suitable as the ingredient for pasta product.

Trough viscosity showed the ability of starch granules to resist heat and destruction, while breakdown viscosity showed they were susceptible to heat and shear force (Olatunde et al., 2017). Starch with lower breakdown value indicated there was less granule disruption. Thus it has better paste stability (Otegbayo et al., 2010). Taro flour had the lowest breakdown viscosity, hence it was more stable when contacted with heat.

Setback viscosity related to starch retrogradation. Starch with higher setback value tends to have higher retrogradation and this was appropriate in the noodle-making (Otegbayo et al., 2010). Modified potato starch and modified banana starch could aid in making the pasta texture firmer.

The lowest to the highest value of pasting temperature were modified potato starch, modified banana starch, and taro flour. The pasting temperature indicated the minimum temperature for the starch to be heated (Kaur and Singh, 2005). Taro flour had the highest pasting temperature which showed that it was more resistant to swelling and breaking down of its starch granules.

Taro flour had low oxalate content (Table 1). This could happen during the processing of taro flour such as soaking the taro chips inside brine solution. The tannin test of taro flour resulted in negative, which indicates no trace of tannin was found in the flour.

The lowest amylose content to the highest was taro flour, modified potato starch, and modified banana starch. Banana starch had higher amylose content; it could form a firmer gel than modified potato starch and taro flour (Olatunde et al., 2017). The lowest starch content to the highest was taro flour, modified banana starch, and modified potato starch. The starch content of those three ingredients was high.

The highest to lowest water absorption capacity was found on taro flour, modified potato starch then modified banana starch. Water absorption capacity showed the bond between amylose and amylopectin chains. The lower the water absorption capacity; thus, the bond between the chain became closer (Otegbayo et al., 2010). Modified banana starch could form a firmer gel in the pasta texture since it 
Table 1. Physical, chemical and functional properties of modified banana starch, modified potato starch, and taro flour

\begin{tabular}{lccc}
\hline Analysis & $\begin{array}{c}\text { Modified Banana } \\
\text { Starch }\end{array}$ & $\begin{array}{c}\text { Modified Potato } \\
\text { Starch }\end{array}$ & Taro Flour \\
\hline Colour (Hue) & $80.40 \pm 1.75$ & $62.72 \pm 0.30$ & $81.95 \pm 0.95$ \\
\hline L & $82.62 \pm 1.68$ & $92.97 \pm 0.14$ & $87.30 \pm 1.16$ \\
A & $1.71 \pm 0.22$ & $3.86 \pm 0.16$ & $1.51 \pm 0.28$ \\
B & $10.21 \pm 0.57$ & $7.49 \pm 0.39$ & $10.62 \pm 1.11$ \\
Bulk density (g/ml) & $0.73 \pm 0.01$ & $0.76 \pm 0.02$ & $0.69 \pm 0.01$ \\
\hline Viscosity (cP) & & & \\
PV & $3182.33 \pm 352.85$ & - & $964.33 \pm 325.20$ \\
\hline TV & $3186 \pm 353.45$ & - & $808 \pm 230.10$ \\
\hline BV & $-3.67 \pm 1.1547$ & - & $156.33 \pm 99.90$ \\
\hline FV & $5511.33 \pm 808.29$ & - & $1166.33 \pm 278.89$ \\
\hline SB & $2325.33 \pm 455.06$ & $1659.33 \pm 654.89$ & $358.33 \pm 50.50$ \\
\hline PT ( ${ }^{\circ}$ C) & $82.6 \pm 0.43$ & $78.48 \pm 14.69$ & $87.8 \pm 0.69$ \\
Calcium oxalate & - & - & $37.67 \pm 0.04$ \\
content (mg/ 100 g) & & & \\
\hline Tannin test & - & - & $11.58 \pm 2.33$ \\
\hline Amylose content (\%) & $61.59 \pm 2.85$ & $43.68 \pm 0.63$ & $66.54 \pm 4.13$ \\
\hline Starch content (\%) & $67.55 \pm 0.52$ & $77.90 \pm 2.21$ & $1.79 \pm 0.25$ \\
Water absorption & $0.88 \pm 0.52$ & $0.95 \pm 0.32$ & $1.40 \pm 0.19$ \\
capacity (g/g) & & $1.23 \pm 0.09$ & $2.55 \pm 0.13$ \\
\hline $\begin{array}{l}\text { Oil absorption } \\
\text { capacity (g/g) }\end{array}$ & $1.29 \pm 0.21$ & $6.40 \pm 0.08$ & $21.87 \pm 1.49$ \\
\hline Swelling power (g/g) & $6.12 \pm 0.19$ & $13.56 \pm 0.40$ & \\
\hline Solubility (\%) & $16.30 \pm 0.63$ & & \\
\hline & & & \\
\hline Not anayze & & & \\
\hline
\end{tabular}

$(-)$ : Not analyzed

has closer polysaccharides chains. The lowest oil absorption capacity to the highest was found in modified potato starch, modified banana starch, and taro flour respectively. If the flour had high oil absorption capacity, then it suited to make food that used cooking oil, for example, to make bread (Singh et al., 2017).

The starch ability to absorb water and swell in a water excess condition is called swelling power (Olatunde et al., 2007). During the heat moisture treatment of starch, the molecule bonds were weakened; thus, the increment of swelling power would occur (Pranoto et al., 2014). The highest swelling power to the lowest was modified potato starch, modified banana starch, and taro flour; hence taro flour and modified banana starch were more resistant to shear force.

Solubility occurred if the crystalline in the starch were destroyed because of heating and the water molecule formed a hydrogen bond toward the leaching of amylose and amylopectin (Ratnayake et al., 2002). Amylose and amylopectin ratio affects the interaction between starch chains in the crystalline and amorphous phase. If the amylose bonds happen to be weak, it could cause the solubility to increase (Pranoto et al. 2014). The lowest to the highest solubility was found in modified potato starch, modified banana starch, and taro flour respectively; thus, modified potato starch and modified banana starch were more resistant to granule leaching.

Physicochemical Properties of Taro Flour Based Spaghetti

Table 2 showed the effect of the composition of composite flour from flour and starch proportion on taro flour-based spaghetti. Protein content could enhance the nutritional quality of a product, but in the taro based-pasta, the protein content was considered low compared to wheat-based pasta.

Table 2. The analysis of the proportion of modified banana starch, modified potato starch, and taro flour

\begin{tabular}{lccccc}
\hline \multirow{2}{*}{ Analysis } & \multicolumn{5}{c}{ The Proportion of Modified Banana Starch, Modified Potato Starch and Taro } \\
& \multicolumn{5}{c}{ Flour } \\
\cline { 2 - 5 } & $0: 30: 70$ & $7.5: 22.5: 70$ & $15: 15: 70$ & $22.5: 7.5: 70$ & $30: 0: 70$ \\
\hline $\begin{array}{l}\text { Protein } \\
\text { Content (\%) }\end{array}$ & $0.19^{\mathrm{b} A \mathrm{AB}} \pm 0.05$ & $0.18^{\mathrm{cB}} \pm 0.12$ & $0.22^{\mathrm{abAB}} \pm 0.01$ & $0.24^{\mathrm{aA}} \pm 0.07$ & $0.23^{\mathrm{abA}} \pm 0.07$ \\
\hline
\end{tabular}

Note: Numbers followed by the same small alphabets mean significantly different $(p<0.05)$ while numbers followed by the same capital alphabets mean highly significantly different $(p<0.01)$.

\section{Protein Content}

The protein content range was from $0.18 \%$ to $0.24 \%$ which was considered very low compared to commercial durum and non-wheat (rice and corn flour) spaghetti with $16.02 \%$ and $8.27 \%$ as well as the gluten-free soybean-rice-mocafcorn spaghetti with 7.75\%-13.89\% (Mayasti et al., 2018). 
The flour and starch used in the spaghetti making had low protein content. But as the number of modified banana starch increased, the protein content became higher. Banana starch $(0.28 \%)$ had higher protein content than potato starch $(0.13 \%)$ (Yadav et al., 2016).

\section{Crude Fiber Content}

Dietary fiber is important to the body since it helps to maintain healthy laxation and reduce cardiovascular disease and cancer risks (Madhu et al., 2017). In a wheatbased pasta, it was reported that the dietary fiber was 3.2\% (Dhiraj and Prabhasankar, 2013) while in a wheat flour noodles was $0.08 \%$ (Alemayehu et al., 2016). The spaghetti crude fiber content was within the range.

The effect of the flour and starch proportion was significantly different $(p<0.05)$ toward the crude fiber content. The result of each proportion was $2.62 \% ; 1.97 \% ; 2.31 \% ; 2.02 \%$; $1.99 \%$. The highest crude fiber content was the proportion of $0 \%: 30 \%: 70 \%$ while the lowest was $7.5 \%: 22.5 \%: 70 \%$. The potato $(0.02 \%)$ and banana starch $(0.04 \%)$ had low fiber content (Lizarazo et al., 2015; Olatunde et al., 2017). In this case, however, modified potato starch had higher fiber content, this might be due to the different varieties of the plant that it had higher fiber content than modified banana starch.

The result of the interaction between the flour and starch proportion with hydrocolloids addition was significantly different $(p<0.05)$ toward the spaghetti crude fiber content. The proportion of $0 \%: 30 \%: 70 \%, 7.5 \%: 22.5 \%: 70 \%$ and 22.5\%:7.5\%:70\% had the highest crude fiber content with xanthan gum addition then followed by carboxymethyl cellulose and Arabic gum (Figure 1). But the 15\%:15\%:70\% and 30\%:0\%:70\% proportion the highest crude fiber content was found in the addition of Arabic gum followed by carboxymethyl cellulose and xanthan gum. Generally, of all interactions except $0 \%: 30 \%: 70 \%$ with the addition of xanthan gum was not significantly different $(p>0.05)$. The highest content was 0\%:30\%:70\% proportion with xanthan gum while the lowest was 7.5\%:22.5\%:70\% with Arabic gum. Xanthan gum could help to increase the fiber content of the flour and starch proportion since it has higher (100\%) fiber content than Arabic gum (80\%) (Wüstenberg, 2015). And the higher portion of modified potato starch gave the higher the crude fiber content

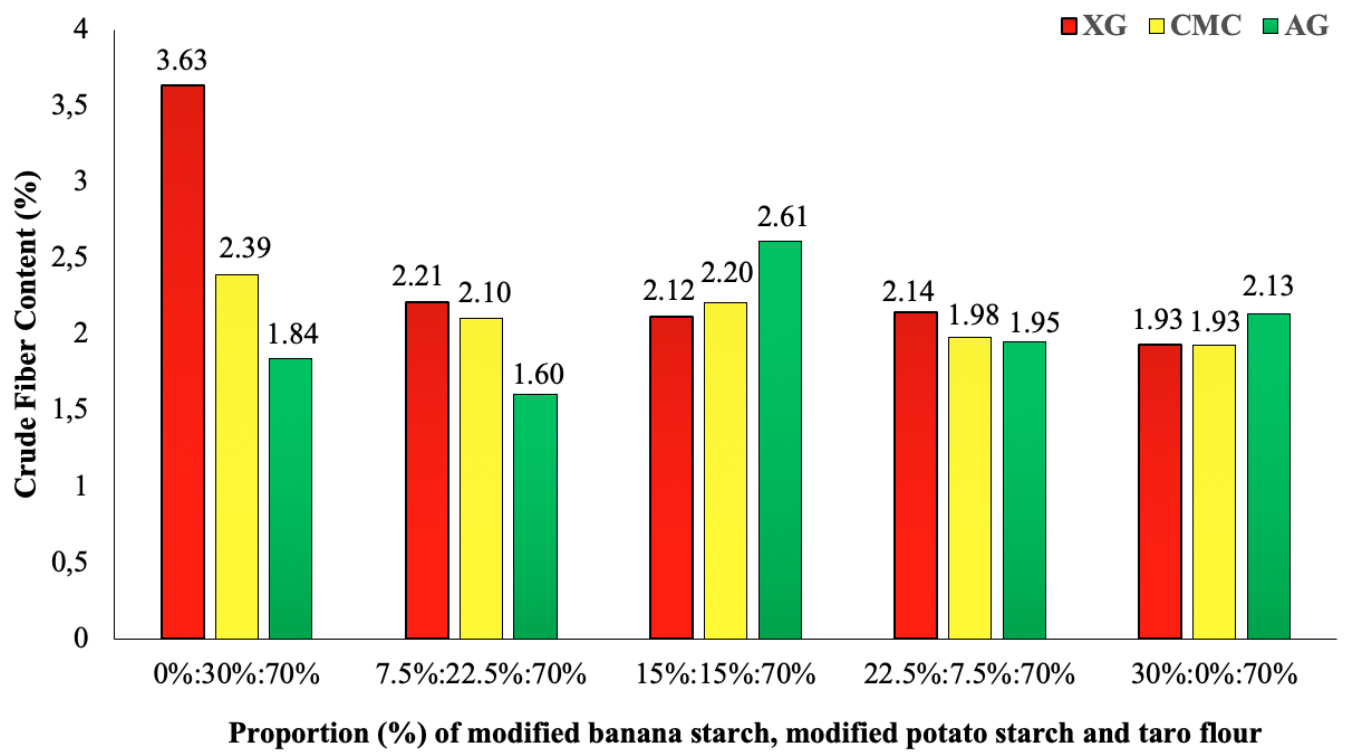

Figure 1. The interaction between flour and starch proportion with hydrocolloids addition toward the spaghetti crude fiber content.

\section{Cooking Time}

The effect of flour and starch proportion was highly significantly different $(p<0.01)$. The starch which has higher pasting temperature will be more resistant to swelling and breaking down of the starch granules (Kaur and Singh, 2005). Modified banana starch and taro flour had higher pasting temperatures than modified potato starch. As the modified banana starch portion increased, the cooking time was also increased.

It was found that the effect of hydrocolloid types toward spaghetti cooking time was significantly different $(p<$ $0.05)$. The longest cooking time was on xanthan gum, followed by carboxymethyl cellulose and Arabic gum. Xanthan gum was stable in the condition of heat while
Arabic gum was denaturized when it contacted with heat (Wüstenberg, 2015). Hydrocolloid addition could increase the cooking time because of the limited water content containing the starch granules in the noodle strand. This condition could delay the starch granules to swell (Kaur et al., 2015).

The cooking time of the interaction between flour and starch proportion with hydrocolloids addition was significantly different $(p<0.01)$. Durum spaghetti needs $10 \mathrm{~min}$ to cook while the gluten-free spaghetti needed 11 to $12 \mathrm{~min}$ (Mayasti et al., 2018). The proportion of 15\%:15\%:70\% and $22.5 \%: 7.5 \%: 70 \%$ had the highest number of cooking time with xanthan gum addition with $11.45 \mathrm{~min}$ and 11.21 min (Figure 2), and those numbers were in the gluten-free 


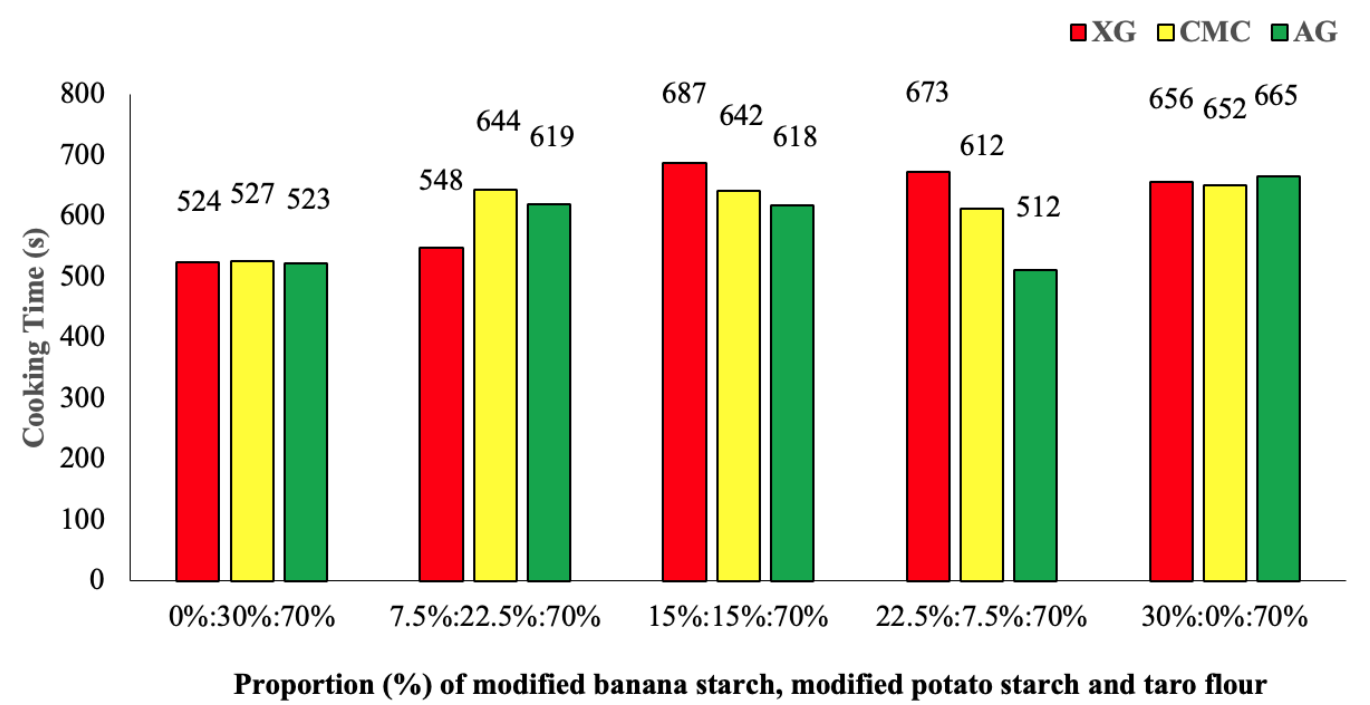

Figure 2. The effect of interaction between the flour and starch proportion with hydrocolloids addition towards spaghetti cooking time.

spaghetti range. Xanthan gum addition was chosen over the other two hydrocolloids since it was more resistant to heat that could prevent more granule leaching.

\section{Cooking Loss}

It was found that the effect of hydrocolloid types was significantly different $(p<0.01)$ toward the spaghetti cooking loss. The highest cooking loss was on Arabic gum $(36.55 \%)$ while the lowest one was on xanthan gum (30.65\%). Xanthan gum addition was found better than the Arabic gum because it was stable on heat and had the ability to form a thin film that can act as gluten meanwhile Arabic gum which acted in emulsification was denaturized when contacted with heat. Emulsifier could lessen the swelling of starch and amylose leaching when it was heated (Waruwu et al., 2015; Wüstenberg, 2015; Gomez and Sciarini, 2015).

The cooking loss of the flour and starch proportion was not significantly different $(p>0.05)$. It was around $30 \%$ $36 \%$. The cooking loss of each proportion respectively was $36.7 \% ; 32.97 \% ; 33.19 \% ; 30.94 \% ; 33.04 \%$ with the least small one was the $22.5 \%: 7.5 \%: 70 \%$ proportion (30.94\%). The result of cooking loss was considered high compared to commercial durum spaghetti and gluten-free rice-corn spaghetti that were around $6 \%$. But the glutenfree soybean-rice-mocaf-corn spaghetti had high cooking loss around $17 \%$ to $30 \%$. This happened since soybean flour had very low amylose content; thus as its portion increased, the ability to retrograde was lower, causing to higher cooking loss (Mayasti et al., 2018). Taro flour had very low amylose content than the other two starches and since it had the largest portion which causing high cooking loss.

\section{Elongation}

The effect of the flour and starch proportion was significantly different $(p<0.01)$ toward spaghetti elongation. The elongation results were around $13 \%$ to $26 \%$, to which these numbers were so far compared to the commercial spaghetti which was $251.75 \%$ and glutenfree soybean-rice-mocaf-corn spaghetti that was around $200 \%$ until 342,32\% (Mayasti et al., 2018). Noodles made of high amylose flour had higher elongation (Afifah and Ratnawati, 2017). Firm texture noodles had higher amylose content and good quality of retrogradation (Herawati et al., 2017). Flour with high amylose content could increase the elongation of noodles. In this case, taro flour had the biggest portion in the proportion and far smaller amylose content than modified-banana and potato starch which caused the elongation to be far lower than another glutenfree spaghetti.

It was also found that hydrocolloids types were significantly different $(p<0.01)$ toward the spaghetti elongation. The highest elongation percentage was on xanthan gum (20.19\%); meanwhile, the lowest elongation percentage was on carboxymethyl cellulose (16.69\%). The addition of xanthan gum could form a firm and hard dough compared to other types of hydrocolloids. Hydrocolloids could improve the quality of texture (Kaur et al., 2015).

The spaghetti elongation of the interaction between flour and starch proportion with hydrocolloids addition was significantly different $(p<0.01)$. The highest elongation percentage was the interaction of flour and starch proportion of $15 \%: 15 \%: 70 \%$ with xanthan gum $(25.78 \%)$ while the lowest was the interaction of $22.5 \%: 7.5 \%: 70 \%$ with carboxymethyl cellulose (13.34\%) (Figure 3). Noodles made of high amylose flour could increase the extensibility so that it could have a higher elongation percentage (Afifah and Ratnawati, 2017; Herawati et al., 2017). The interaction of $15 \%: 15 \%: 70 \%$ proportion might have lower amylose content than the 22.5\%:7.5\%:70\%, but the effect of xanthan gum resulted in higher elongation percentage because it could act as a gluten to trap the starch granules and had good stability in heat that occurred when the spaghetti was boiled before the analysis of elongation percentage. 


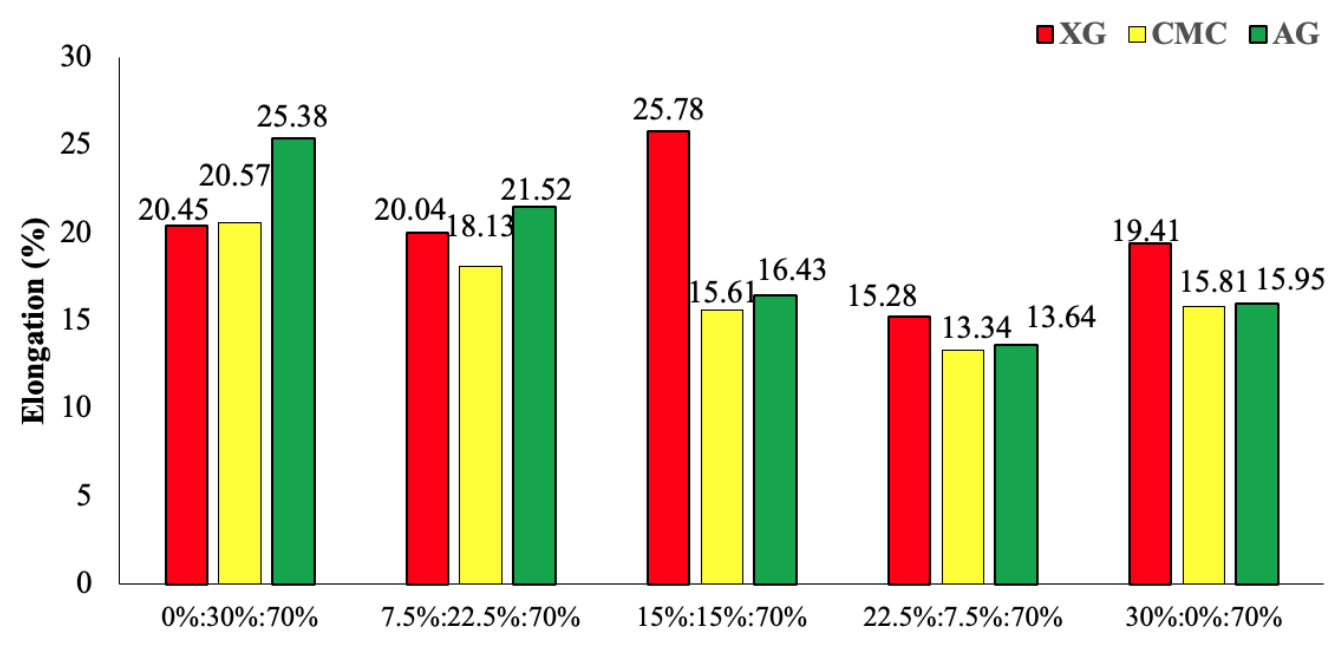

Proportion (\%) of modified banana starch, modified potato starch and taro flour

Figure 3: The effect of the interaction between flour and starch proportion with hydrocolloids addition towards the spaghetti elongation

\section{CONCLUSION}

It was found that the increment of banana starch could cause longer cooking time and higher protein content while the increment of modified potato starch caused the crude fiber content to increase. The spaghetti with flour and starch proportion 15\%:15\%:70\% and 22.5\%:7.5\%:70\% had a small difference in cooking time and their results were considered fine. The crude fiber content was at the range of wheat-based pasta. But the protein content and elongation had far smaller number compared to another gluten-free spaghetti while the cooking loss was very high compared to the commercial non-wheat spaghetti. As for hydrocolloids, xanthan gum addition could cause longer cooking time, lesser cooking loss and higher elongation and crude fiber content.

\section{ACKNOWLEDGMENT}

This research was funded by PT. Indofood Sukses Makmur Tbk through the program of Indofood Riset Nugraha 2017/2018 (SKE. 029/VIII/CC/2017).

\section{REFERENCES}

Adebowale K. O., Olu-Owolabi B. I., Olayinka O.O. and Lawal O. S. 2005. Effect of heat moisture treatment and annealing on physicochemical properties of red sorghum starch. African Journal of Biotechnology. 4(9): 928-933.

Afifah N. and Ratnawati L. 2017. Quality assessment of dry noodles made from blend of mocaf flour, rice flour and corn flour. IOP Conf. Series: Earth and environmental science. 101(2017): 1-12.

Alemayehu D., Desse G., Abegaz K., Desalegn B. B. and Getahun D. 2016. Proximate, mineral composition and sensory acceptability of home made noodles from stinging nettle (Urtica simensis) leaves and wheat flour blends. International Journal of Food Science and Nutrition Engineering. 6(3): 55-61.

Anderson R. A. 1982. Water absorption and solubility and amylograph characteristics on roll-cooked small grain products. Cereal Chemistry. 59: 265-269.

AOAC. 1995. "Official methods of analysis of the association of official analytical chemists". AOAC, Washington.

Apriyantono A., Fardiaz D., Puspitasari N. L., Sedarnawati and Budiyanto S. 1989. "Analisa pangan". PAU Pangan dan Gizi, Bogor.

BSN. 1998. SNI 01-4454-1998 Syarat mutu spagheti. Badan Standarisasi Nasional.

Balaban D. V., Popp A., Radu F. I. and Jinga M. 2019. Hematologic manifestations in celiac disease-a practical review. Medicina. 55(373): 1-8.

Dhiraj B. and Prabhasankar P. 2013. Influence of wheat-milled products and their additive blends on pasta dough rheological, microstructure, and product quality characteristics. International Journal of Food Science. 2013: 1-11.

Gomez M. and Sciarini L. S. 2015. Gluten-free bakery products and pasta. In "Advances in the understanding of gluten related pathology and the evolution of gluten-free foods", pp.565-604. OmniaScience, Barcelona.

Hager A-S., Zannini E. and Arendt E. K. 2012. Gluten-free pasta-advances in research and commercialization. Cereal Foods World. 57(5): 225229.

Herawati E. R. N., Ariani D., Miftakhussolikhah, Yosieto E., Angwar M. and Pranoto Y. 2017. Sensory and textural characteristics of noodle made of ganyong flour (Canna edulis Kerr.) and arenga starch (Arenga pinnata Merr.). IOP Conf. Series: Earth and environmental science. 101(2017): 1-7.

Hutching J. B. 1999. "Food and appearance, $2^{\text {nd }}$ ed". Aspen Publications, Gaithersburg.

Jacobs H. and Delcour J. A. 1998. Hydrothermal modifications of granular starch, with retention of the granular structure: A review. J of Agr and Food Chem. 46: 2895-2905.

Kaur M. and Singh N. 2005. Studies on functional, thermal and pasting properties of flours from different chickpea (Cicer arietinum L.) cultivars. Food Chemistry. 91(2005): 403-411.

Kaur M., Shevkani K., Singh N., Sharma P. and Kaur S. 2015. Effect of guar gum and xanthan gum on pasting and noodle-making properties of potato, corn and mung bean starches. J Food Sci Technol. 52(12): 8113-8121.

Laleg K., Cassan D., Barron C., Prabhasankar P. and Micard V. 2016. Structural, culinary, nutritional and anti-nutritional properties of high protein, gluten free, 100\% legume pasta. Plos ONE. 11(9): 1-19.

Leach H. W., McCowan L. D. and Schoch T. J. 1959. Structure of the starch granules. In: Swelling power and solubility patterns of different starches. Cereal chemistry. 36: 534-544.

Leite T. D., Nicoletti J. F., Penna A. L. B. and Franco C. M. L. 2012. Effect of addition of different hydrocolloids on pasting, thermal and rheological properties of cassava starch. Ciencia e Tecnologia de Alimentos. 32(3): 579-587.

Lizarazo S. P., Hurtado G. G. and Rodriguez L. F. 2015. Physicochemical and morphological characterization of potato starch (Solanum tuberosum L.) as raw material for the purpose of obtaining bioethanol. Agronomia Colombiana. 33(2): 244-252.

Madhu C., Krishna K. M., Reddy K. M., Lakshmi P. J. and Kelari E. K. 2017. Estimation of crude fibre content from natural food stuffs and its laxative activitiy induced in rats. International Journal of Pharma Research and Health Sciences. 5(3): 1703-1706. 
Mayasti N. K. I., Ushada M. and Ainuri M. 2018. Analisa mutu produk spageti berbasis tepung beras, jagung, mocaf, dan kedelai. PANGAN. 27(2): 129-140.

Noda T., Fujikami S., Miura H., Fukushima M., Takigawa S., MatsuuraEndo C., Kim S. J., Hashimoto N. and Yamauchi H. 2006. Effect of potato starch characteristics on the textural properties of korean-style cold noodles made from wheat flour and potato starch blends. Food Sci. Technol. Res. 12(4): 278-283.

Olatunde G. O., Arogundade L. K. and Orija O. I. 2017. Chemical, functional and pasting properties of banana and plantain starches modified by pre-gelatinization, oxidation and acetylation. Cogent Food \& Agriculture. 3(2017): 1-12.

Otegbayo B., Lana O. and Ibitoye W. 2010. Isolation and physicochemical characterization of starches isolated from plantain (Musa paradisiaca) and cooking banana (Musa sapientum). Journal of Food Biochemistry. 34(2010): 1303-1318.

Padalino L., Mastromatteo, M., Sepielli G. and Nobile M. A. D. 2011. Formulation optimization of gluten-free functional spaghetti based on maize flour and oat bran enriched in $\beta$-glucans. Materials. 4: 21192135.

Parzanese I., Qehajaj D., Patrinicola F., Aralica M., Chiriva-Internati M., Stifter S., Elli L. and Grizzi F. 2017. Celiac disease: From pathophysiology to treatment. World J Gastrointest Pathophysiol. 8(2): 27-38.

Pereira P. R., Silva T., Vericimo M. A., Paschoalin V. M. F. and Teixeira G. A. P. B. 2015. Crude extract from taro (Colocasia esculenta) as a natural source of bioactive proteins able to stimulate haematopoietic cells in two murine models. Journal of Functional Foods. 18(2015): 333-343.

Poddighe D., Rakhimzhanova M., Marchenko Y. and Catassi C. 2019. Pediatric celiac disease in central and East Asia: current knowledge and prevalence. Medicina. 55(11): 1-8.

Pranoto Y., Rahmayuni, Haryadi and Rakshit S. K. 2014. Physicochemical properties of heat moisture treated sweet potato starches of selected Indonesian varieties. International Food Research Journal. 21(5): 2031-2038.

Ratnayake W. S., Hoover R. and Warkentin T. 2002. Pea starch: composition, structure, and properties - a review. Starch/Stärke. 54(2002): 217-234.
Rashmi D. R., Raghu N., Gopenath T. S., Pradeep P., Pugazhandhi B., Murugesan K., Ashok G., Ranjith M.S., Chandrashekrappa G. K. and Kanthesh M. B. 2018. Taro (Colocasia esculenta): an overview. Journal of Medicinal Plants Studies. 6(4): 156-161.

Sathe S. K. and Salunkhe D. K. 1981. Isolation, partial characterization and modification of the great northern bean (Phaseolus vulgaricus L.). Journal Food Sci. 46: 617-621.

Singh R., Ranvir S. and Madan S. 2017. Comparative study of the properties of ripe banana flour, unripe banana flour and cooked banana flour aiming towards effective utilization of these flours. Int. J. Curr. Microbiol. App. Sci. 6(8): 2003-2015.

Stuknyte M., Cattaneo S., Pagani M. A., Marti A., Micard V., Hogenboom J. and Noni I. D. 2013. Spaghetti from durum wheat: Effect of drying conditions on heat damage, ultrastructure and in vitro digestibility. Food Chemistry. 149(2014): 40-46.

Temesgen M. and Retta N. 2015. Nutritional potential, health and food security benefits of taro Colocasia esculenta (L.): A review. Food Science and Quality Management. 36: 23-30.

Ukpabi U. J. and Ejidoh J. I. 1989. Effect of deep oil frying on the oxalate content and the degree of itching of cocoyams (Xanthosoma and Colocasia spp.) Technical Paper presented at the $5^{\text {th }}$ Annual Conference of the Agricultural Society of Nigeria. Federal University of Technology, Owerri, Nigeria, 3-6 Sept.

USDA. 2009. Pasta Product. The U. S. Deparment of Agriculture (USDA).

Waliszewski, K. N., M. A. Aparicio, L. A. Bello, dan J. A. Monroy. 2003. Changes of banana starch by chemical and physical modification. Carbohydrate Polymers. 52(2003): 237-242.

Waruwu F., Julianti E. and Ginting S. 2015. Physicochemical and sensory characteristics evaluation of bread from composite flour (rice, cassava, potato starch and soybean) with the addition of xanthan gum. Jurnal Rekayasa Pangan dan Pertanian. 3(4): 448-457.

Wüstenberg T. 2015. General overview of food hydrocolloids. "Cellulose and cellulose derivatives in the food industry: Fundamentals and applications, 1 ${ }^{\text {st }}$ ed", pp 1-68. Wiley-VCH GmbH, Weinheim.

Yadav R. B., Kumar N. and Yadav B. S. (2016). Characterization of banana, potato and rice starch blends for their physicochemical and pasting properties. Cogent Food \& Agriculture. 2: 1-12. 